\title{
Prevalence of Skin and Skin-Related Diseases in the Rochester Epidemiology Project and a Comparison with Other Published Prevalence Studies
}

\author{
Louise K. Andersen ${ }^{\mathrm{a}}$ Mark D.P. Davis ${ }^{\mathrm{b}}$

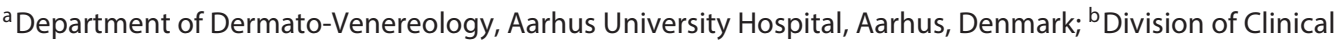 \\ Dermatology, Mayo Clinic, Rochester, Minn., USA
}

\section{Key Words}

Epidemiology $\cdot$ Prevalence $\cdot$ Skin diseases $\cdot$ Skin-related diseases

\begin{abstract}
In Olmsted County, Minn., USA, reliable, population-based epidemiologic research studies can be performed because of a unique medical records linkage system, the Rochester Epidemiology Project (REP). Our objective was to summarize the epidemiologic data describing the prevalence of skin and skin-related diseases derived from the REP and to compare the findings with those from other studies worldwide. Retrospectively, we reviewed the results of populationbased REP studies reporting the prevalence of skin and skinrelated diseases over more than 4 decades and compared them to other published prevalences globally. Prevalences from the REP reported per 100,000 persons were as follows: hidradenitis suppurativa, 130.0; psoriasis, 700.0; psoriatic arthritis in 1992, 100.0, and in 2000, 160.0; Behçet disease, 5.2; scleroderma, 13.8; dermatomyositis, 21.42; systemic lupus erythematosus (SLE), from 30.5 to 122.0 suspected SLE, 32.8; combined SLE, 41.8; discoid lupus erythematosus, 27.6, and cutaneous lupus erythematosus, 70.4 and 73.2 (from 2 stud-
\end{abstract}

ies). Many of the population-based prevalences of specific skin and skin-related diseases derived from the REP are different from those estimated globally. Suggested reasons for disparity in the prevalences globally may include differences in the type of reported prevalence, study methodology, geographic areas, ethnic groups, age distribution, and socioeconomic status.

(c) 2016 S. Karger AG, Basel

\section{Introduction}

Skin and skin-related diseases cause a global health burden, and the epidemiology of disease must be understood in order to plan for the allocation of health care resources. Epidemiologic data include measures of incidence and prevalence. We previously summarized the incidence (a measure of new cases in a population over a given period) of skin and skin-related diseases in Olmsted County, Minn., USA, from the Rochester Epidemiology Project (REP) data [1].

Prevalence is defined as the proportion of a population found to have a disease over a specified period (period prevalence) or at a specific point in time (point preva-

\section{KARGER}

E-Mail karger@karger.com

www.karger.com/drm
(C) 2016 S. Karger AG, Basel

$1018-8665 / 16 / 2323-0344 \$ 39.50 / 0$
Mark D.P. Davis, MD

Division of Clinical Dermatology, Mayo Clinic

200 First Street SW

Rochester, MN 55905 (USA)

E-Mail davis.mark2@ mayo.edu 


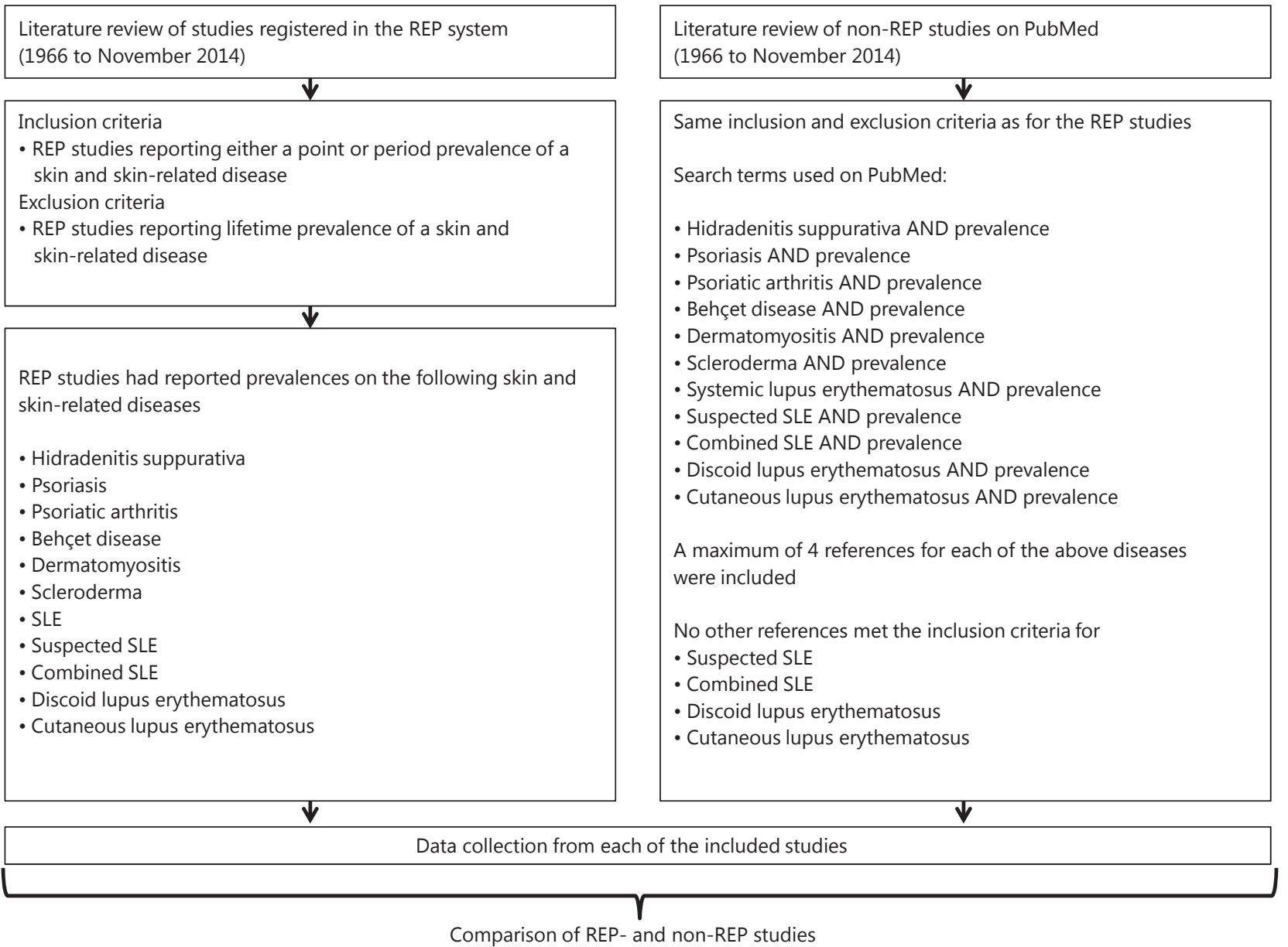

Fig. 1. Flowchart. SLE = Systemic lupus erythematosus.

lence). The prevalence of skin and skin-related diseases may change over time and vary depending on geographic areas, age distributions, and ethnic groups.

In Olmsted County, in southeastern Minnesota, population-based epidemiologic studies can be derived from the REP, a unique records linkage research infrastructure that has existed since 1966. The REP permits access to the medical records of virtually all persons living in this geographically isolated population $[2,3]$. The population of Olmsted County is relatively small (146,000 persons according to 2011 census data) and mostly white (i.e. less racially diverse than the USA as a whole).

Among patients seeking health care in Olmsted County, skin disorders are reported as the most prevalent, followed by osteoarthritis, joint disorders, and back prob- lems [4]. Since almost half the Olmsted County population has received a diagnosis of a skin disorder, we decided to gather all available published prevalence data on skin and skin-related diseases from the REP data published over the past 4 decades. In addition, we compared the reported prevalence data from the REP with other reported prevalence data.

\section{Methods}

For further details, see the supplementary materials (for all online suppl. material, see www.karger.com/doi/10.1159/000444580) (fig. 1). 
Table 1. Studies of prevalence rate of skin and skin-related disease using the REP, Olmsted County, Minn., USA

\begin{tabular}{llllc}
\hline Reference & Disease & $\begin{array}{l}\text { Age, } \\
\text { years }\end{array}$ & $\begin{array}{l}\text { Date/period of } \\
\text { prevalence estimate }\end{array}$ & Prevalence \\
\hline Shahi et al. [5] & HS & All & Jan 1, 2009 & $127.8(108.9-146.8)$ \\
Shbeeb et al. [6] & Psoriasis & $\geq 18$ & Jan 1, 1992 & $700.0(650.0-750.0)$ \\
Shbeeb et al. [6] & Psoriatic arthritis & $\geq 18$ & Jan 1, 1992 & $101.0(80.0-120.0)$ \\
Wilson et al. [7] & Psoriatic arthritis & All & Jan 1, 2000 & $158.0(132.0-185.0)$ \\
Calamia et al. [8] & BD & $\geq 18$ & 2000 & $5.2(0.64-9.84)$ \\
Bendewald et al. [9] & DM & All & Jan 1, 2007 & $21.42(13.07-29.77)$ \\
Michet et al. [10] & Scleroderma & All & Jan 1, 1980 & $13.8(4.2-23.4)$ \\
Kurland et al. [11] & SLE & All & Jan 1, 1968 & 48.0 \\
Michet et al. [10] & SLE & All & Jan 1, 1980 & $40.0(23.5-57.5)$ \\
Uramoto et al. [12] & SLE & All & Jan 1, 1993 & $122.0(97.0-147.0)$ \\
Jarukitsopa et al. [13] & SLE & All & Jan 1, 2006 & $30.5(21.1-39.9)$ \\
Michet et al. [10] & Suspected SLE & All & Jan 1, 1980 & $32.8(18.1-47.5)$ \\
Nobrega et al. [14] & Combined SLE & All & Jan 1, 1966 & 41.8 \\
Michet et al. [10] & Discoid lupus erythematosus & All & Jan 1, 1980 & $27.6(14.1-41.1)$ \\
Durosaro et al. [15] & CLE & All & Jan 1, 2006 & $73.2(58.3-88.2)$ \\
Jarukitsopa et al. [13] & CLE & All & Jan 1, 2006 & $70.4(55.9-84.8)$ \\
\hline
\end{tabular}

CLE $=$ Cutaneous lupus erythematosus. Figures in parentheses indicate 95\% confidence intervals. Prevalence estimate: the prevalence is a point prevalence if it was reported for a specific point in time (i.e. a specific day and year), but the prevalence is a period prevalence if it was reported for a specified period (e.g. months or years). In Nobrega et al. [14], combined SLE is defined as classic SLE (positive LE cell test and $\geq 3$ major systemic manifestations of LE) plus rheumatoid arthritis with LE (previous rheumatoid arthritis with positive LE cell test and $\geq 3$ major systemic manifestations of LE). As for Durosaro et al. [15] and Jarukitsopa et al. [13], both studies reported the point prevalence of cutaneous lupus erythematosus for the Olmsted County population in January 2006. Differences in these prevalences are due to differences in the methodology used in defining the denominator and in adjusting the population. Moreover, these prevalence estimates for cutaneous lupus erythematosus are underestimates since they were derived from incident cases in Olmsted County from 1965 to 2002.

\section{Results}

A total of 11 REP studies met the study inclusion criteria. The majority of the REP data were reported as point prevalence and were as follows (prevalences are expressed per 100,000 persons): hidradenitis suppurativa (HS), 130.0; psoriasis, 700.0; psoriatic arthritis in 1992, 100.0, and in 2000, 160.0; Behçet disease (BD), 5.2; scleroderma, 13.8; dermatomyositis (DM), 21.42; systemic lupus erythematosus (SLE) in 1968, 48.0; SLE in 1980, 40.0; SLE in 1993, 122.0; SLE in 2006, 30.5; suspected SLE, 32.8; combined SLE, 41.8; discoid lupus erythematosus, 27.6; and cutaneous lupus erythematosus, 70.4 and 73.2 (prevalences were reported from 2 studies). Table 1 summarizes the abstracted data for each REP study [5-15].

Table 2 summarizes data abstracted from each of the included non-REP studies [16-43]. The prevalences of HS in Denmark and France were significantly higher than in Olmsted County $[5,16,17]$. The prevalence of HS in South Wales was similar to the prevalence in Olmsted County $[5,18]$. The prevalences of psoriasis in Europe were higher than the prevalence reported for Olmsted County [6, 21-23]. For psoriatic arthritis, the prevalences were reported to be lower in the Czech Republic [24] and Northwest Greece [25] compared to Olmsted County [6] but much higher both in Norway [26] and Italy [27]. The prevalence of BD was significantly higher in Turkey [31] compared to Olmsted County [8], other European countries and Taiwan [28-30]. The prevalence of DM in central Greece [35] was relatively high compared to the prevalences in the USA, Australia, and Argentina $[9,32-34]$. The prevalences of scleroderma in Detroit, Mich., USA [36], areas of Canada [37, 38], and South Australia [39] were higher than the prevalence reported in Olmsted County [10]. The prevalence of SLE varied considerably over the years in Olmsted County, but was similar to other white populations in Europe and the USA [10-13, 40-42]. 
Table 2. Prevalence of skin and skin-related diseases globally

\begin{tabular}{|c|c|c|c|c|c|c|c|}
\hline Disease & Reference & $\begin{array}{l}\text { Geographic } \\
\text { location }\end{array}$ & Study methodology & $\begin{array}{l}\text { Ages of } \\
\text { persons in } \\
\text { population, } \\
\text { years }\end{array}$ & $\begin{array}{l}\text { Date of } \\
\text { prevalence } \\
\text { estimate }\end{array}$ & Prevalence per 100,000 & $95 \% \mathrm{CI}$ \\
\hline \multirow[t]{5}{*}{ HS } & \multirow[t]{2}{*}{$\begin{array}{l}\text { Jemec et al. } \\
\text { [16] }\end{array}$} & \multirow[t]{2}{*}{ Denmark } & $\begin{array}{l}\text { Random sample }(\mathrm{n}=793) \text { was invited for } \\
\text { a general health examination by a standard } \\
\text { letter; } 599 \text { persons }(75.5 \%) \text { responded and } \\
\text { were examined }\end{array}$ & $\geq 15-69$ & 1992 & $1,000.0$ & $400.0-2,200.0$ \\
\hline & & & $\begin{array}{l}\text { Consecutive series of patients at a sexually } \\
\text { transmitted diseases clinic; } 507 \text { patients } \\
\text { were examined }\end{array}$ & All & $\begin{array}{l}\text { Two 6-month } \\
\text { periods } \\
(1992-1995)\end{array}$ & $4,100.0$ & $3,000.0-6,000.0$ \\
\hline & $\begin{array}{l}\text { Revuz et al. } \\
{[17]}\end{array}$ & France & $\begin{array}{l}\text { Survey was mailed to a representative } \\
\text { sample of the French population }(\mathrm{n}= \\
10,000) \text { and was returned by } 68.9 \%(6,887 \\
\text { of } 10,000)\end{array}$ & $\geq 15$ & 2002 & 970.0 & $790.0-1,250.0$ \\
\hline & $\begin{array}{l}\text { Harrison } \\
\text { et al. [18] }\end{array}$ & South Wales & $\begin{array}{l}\text { Retrospective analysis of all registered } \\
\text { patients at } 2 \text { general practices; practice A } \\
(\mathrm{n}=5,652) \text { was an industrial valley } \\
\text { community and practice } B(n=6,919) \text { an } \\
\text { urban practice }\end{array}$ & All & Not reported & $\begin{array}{l}\text { Practice A: } 140.0 \\
\text { Practice B: } 190.0\end{array}$ & \\
\hline & $\begin{array}{l}\text { Cosmatos } \\
\text { et al. [19] }\end{array}$ & USA & $\begin{array}{l}\text { Retrospective analysis of a large health } \\
\text { insurance claims database }(\mathrm{n}=7,929)\end{array}$ & All & 2007 & 53.0 & $51.0-54.0$ \\
\hline \multirow[t]{4}{*}{ Psoriasis } & $\begin{array}{l}\text { Gelfand } \\
\text { et al. [20] }\end{array}$ & USA & $\begin{array}{l}\text { Random sample }(\mathrm{n}=27,220) \text { was asked } \\
\text { standard demographic questions; if a } \\
\text { physician-confirmed diagnosis of psoriasis } \\
\text { was reported, additional questions were } \\
\text { asked }\end{array}$ & All & Not reported & $\begin{array}{l}\text { Whites: } 2,500.0 \\
\text { African-Americans: } 1,300.0\end{array}$ & $\begin{array}{r}2,200.0-2,700.0 \\
700.0-1,800.0\end{array}$ \\
\hline & $\begin{array}{l}\text { Nevitt and } \\
\text { Hutchinson } \\
{[21]}\end{array}$ & Leicester, UK & $\begin{array}{l}\text { Letter with a short description of psoriasis } \\
\text { was sent to } 5,395 \text { patients in a general } \\
\text { medical practice; patients replying } \\
\text { positively were invited for an examination }\end{array}$ & All & Not reported & $1,480.0$ & $1,200.0-1,800.0$ \\
\hline & $\begin{array}{l}\text { Augustin } \\
\text { et al. [22] }\end{array}$ & Germany & $\begin{array}{l}\text { Retrospective analysis of data from a } \\
\text { database of about } 1.3 \text { million nonselected } \\
\text { persons enlisted in a German statutory } \\
\text { health insurance organization covering all } \\
\text { regions in Germany }\end{array}$ & $\begin{array}{l}\text { All } \\
<18\end{array}$ & 2005 & $\begin{array}{l}2,530.0 \\
710.0\end{array}$ & $2,500.0-2,560.0$ \\
\hline & $\begin{array}{l}\text { Saraceno } \\
\text { et al. [23] }\end{array}$ & Italy & $\begin{array}{l}\text { Survey was mailed to a representative } \\
\text { sample of the Italian population ( } n=3,500 \\
\text { families) }\end{array}$ & All & Feb 2006 & $2,900.0$ & \\
\hline \multirow[t]{4}{*}{$\begin{array}{l}\text { Psoriatic } \\
\text { arthritis }\end{array}$} & $\begin{array}{l}\text { Hanova } \\
\text { et al. [24] }\end{array}$ & $\begin{array}{l}\text { Czech Republic: } \\
\text { City of Ceske } \\
\text { Budejovice } \\
\text { (urban) and } \\
\text { district of } \\
\text { Cheb (rural) } \\
\end{array}$ & $\begin{array}{l}\text { Retrospective analysis of a population- } \\
\text { based cohort identified from } 2 \text { regions } \\
\text { (total } \mathrm{n}=154,374 \text { ); diagnosis was } \\
\text { confirmed by rheumatologists or } \\
\text { dermatologists }\end{array}$ & $\geq 16$ & Mar 1, 2002 & $\begin{array}{l}\text { City of Ceske Budejovice: } 36.7 \\
\text { District of Cheb: } 63.0\end{array}$ & $\begin{array}{l}25.6-50.9 \\
47.6-81.8\end{array}$ \\
\hline & $\begin{array}{l}\text { Alamanos } \\
\text { et al. [25] }\end{array}$ & $\begin{array}{l}\text { Northwest } \\
\text { Greece }\end{array}$ & $\begin{array}{l}\text { Retrospective analysis of records for } \\
\text { inpatients and outpatients referred to } \\
\text { rheumatology clinics (private and } \\
\text { hospitals) in an area with 500,000 } \\
\text { inhabitants }\end{array}$ & $\geq 16$ & Dec 31, 2001 & 57.0 & $50.0-63.0$ \\
\hline & $\begin{array}{l}\text { Madland } \\
\text { et al. [26] }\end{array}$ & $\begin{array}{l}\text { Bergen, } \\
\text { Norway }\end{array}$ & $\begin{array}{l}\text { Retrospective analysis of data from } \\
\text { rheumatology centers and } 2 \text { private } \\
\text { rheumatologists in a county with } 442,000 \\
\text { inhabitants }\end{array}$ & $\geq 20$ & Jan 1, 2003 & 195.0 & $180.0-210.0$ \\
\hline & $\begin{array}{l}\text { Salaffi et al. } \\
{[27]}\end{array}$ & Italy & $\begin{array}{l}\text { Questionnaires were sent to a random } \\
\text { sample of 3,664 patients selected from the } \\
\text { practice lists of } 16 \text { general practitioners }\end{array}$ & $\geq 18$ & 2004 & 420.0 & $310.0-610.0$ \\
\hline \multirow[t]{4}{*}{$\mathrm{BD}$} & $\begin{array}{l}\text { Salvarani } \\
\text { et al. [28] }\end{array}$ & $\begin{array}{l}\text { Reggio Emilia, } \\
\text { Northern Italy }\end{array}$ & $\begin{array}{l}\text { Retrospective analysis of a population- } \\
\text { based cohort; data were derived from } \\
\text { multiple sources }\end{array}$ & $\geq 18$ & Jan 1, 2005 & 3.8 & $2.0-5.8$ \\
\hline & $\begin{array}{l}\text { Mahr et al. } \\
\text { [29] }\end{array}$ & $\begin{array}{l}\text { Paris } \\
\text { metropolitan } \\
\text { area, France }\end{array}$ & $\begin{array}{l}\text { Questionnaire was mailed to community- } \\
\text { based general physicians, rheumatologists, } \\
\text { dermatologists, and ophthalmologists, and } \\
\text { asked whether they were aware of any } \\
\text { patients with BD (metropolitan area is } \\
\text { home for 1,094,412 adults of whom } 26 \% \\
\text { are of non-European ancestry) }\end{array}$ & $\geq 15$ & 2003 & $\begin{array}{l}\text { All ethnic groups: } 7.1 \\
\text { European: } 2.4 \\
\text { North African: } 34.6 \\
\text { Asian (incl. Turkish): } 17.5 \\
\text { Sub-Saharan African: } 5.1 \\
\text { Noncontinental French: } 6.2\end{array}$ & $\begin{array}{c}3.5-14.4 \\
0.6-7.2 \\
24.4-47.5 \\
10.7-27.2 \\
2.2-11.7 \\
2.8-13.1\end{array}$ \\
\hline & $\begin{array}{l}\text { Yu et al. } \\
{[30]}\end{array}$ & Taiwan & $\begin{array}{l}\text { Retrospective analysis of a population- } \\
\text { based cohort; cases registered with Taiwan } \\
\text { National Health Insurance } \\
\text { (comprising } 1,000,000 \text { beneficiaries) }\end{array}$ & All & 2000 & 1.4 & $0.4-2.3$ \\
\hline & $\begin{array}{l}\text { Azizlerli } \\
\text { et al. [31] }\end{array}$ & $\begin{array}{l}\text { Istanbul, } \\
\text { Turkey }\end{array}$ & $\begin{array}{l}\text { A 2-stage study: identified people with } \\
\text { recurrent oral ulcers by visiting homes }\end{array}$ & $\geq 12$ & Not reported & 420.0 & $3,40.0-510.0$ \\
\hline
\end{tabular}


Table 2 (continued)

\begin{tabular}{|c|c|c|c|c|c|c|c|}
\hline Disease & Reference & $\begin{array}{l}\text { Geographic } \\
\text { location }\end{array}$ & Study methodology & $\begin{array}{l}\text { Ages of } \\
\text { persons in } \\
\text { population, } \\
\text { years }\end{array}$ & $\begin{array}{l}\text { Date of } \\
\text { prevalence } \\
\text { estimate }\end{array}$ & Prevalence per 100,000 & $95 \%$ CI \\
\hline \multirow[t]{4}{*}{$\mathrm{DM}$} & $\begin{array}{l}\text { Furst et al. } \\
{[32]}\end{array}$ & USA & $\begin{array}{l}\text { Retrospective analysis of medical records } \\
\text { in a large managed-care database ( } 35 \\
\text { million insured members) }\end{array}$ & $\geq 18$ & Jan 1,2008 & 5.9 & $5.3-6.5$ \\
\hline & $\begin{array}{l}\text { Tan et al. } \\
{[33]}\end{array}$ & $\begin{array}{l}\text { South } \\
\text { Australia }\end{array}$ & $\begin{array}{l}\text { All muscle biopsy reports from the } \\
\text { Neuropathology Laboratory, Hanson } \\
\text { Institute, were reviewed; patient medical } \\
\text { records were reviewed for clinical } \\
\text { correlation }\end{array}$ & All & $1980-2009$ & 1.97 & \\
\hline & $\begin{array}{l}\text { Rosa et al. } \\
{[34]}\end{array}$ & $\begin{array}{l}\text { Buenos Aires, } \\
\text { Argentina }\end{array}$ & $\begin{array}{l}\text { Cases registered with the Hospital Italiano } \\
\text { Medical Care Program }(\mathrm{n}=140,000 \\
\text { members) }\end{array}$ & All & Jun 1,2009 & 10.22 & $4.9-18.8$ \\
\hline & $\begin{array}{l}\text { Anagnosto- } \\
\text { poulos et al. } \\
{[35]}\end{array}$ & Central Greece & $\begin{array}{l}\text { Mailed questionnaire was followed by } \\
\text { confirmation with clinical examination } \\
\text { and tests of persons with a positive reply } \\
(\mathrm{n}=3,528)\end{array}$ & $\begin{array}{l}\text { Adults } \\
\text { (ages } \\
\text { not } \\
\text { specified) }\end{array}$ & $\begin{array}{l}\text { Apr } 2007 \text { to } \\
\text { Jun } 2008\end{array}$ & 58.0 & $50.0-180.0$ \\
\hline \multirow[t]{4}{*}{$\begin{array}{l}\text { Sclero- } \\
\text { derma }\end{array}$} & $\begin{array}{l}\text { Mayes et al. } \\
{[36]}\end{array}$ & $\begin{array}{l}\text { Detroit, Mich., } \\
\text { USA }\end{array}$ & $\begin{array}{l}\text { Retrospective analysis of the population of } \\
\text { the Detroit Tri-County Area; data were } \\
\text { derived from multiple sources }\end{array}$ & $\geq 18$ & $1989-1991$ & $\begin{array}{l}\text { All ethnic groups: } 24.2 \\
\text { White: } 22.5 \\
\text { Black: } 31.5\end{array}$ & $\begin{array}{l}21.3-27.4 \\
19.7-25.6 \\
28.2-35.2 \\
\end{array}$ \\
\hline & $\begin{array}{l}\text { Bernatsky } \\
\text { et al [37] }\end{array}$ & $\begin{array}{l}\text { Quebec, } \\
\text { Canada }\end{array}$ & $\begin{array}{l}\text { Retrospective analysis of Quebec physician } \\
\text { billing and hospitalization databases } \\
\text { (covering } 7.5 \text { million people) }\end{array}$ & All & 2003 & 44.3 & $41.1-47.6$ \\
\hline & $\begin{array}{l}\text { Thompson } \\
\text { and Pope } \\
{[38]}\end{array}$ & $\begin{array}{l}\text { Windsor, } \\
\text { Woodstock, } \\
\text { Sarnia, Ont., } \\
\text { Canada }\end{array}$ & $\begin{array}{l}\text { Case-control study of patients with } \\
\text { scleroderma and } 2 \text { age- and sex-matched } \\
\text { controls from the same rheumatologist's } \\
\text { practice; a questionnaire was mailed to } \\
\text { both groups }\end{array}$ & All & $\begin{array}{l}\text { Not } \\
\text { reported }\end{array}$ & $\begin{array}{l}\text { Windsor: } 7.1 \\
\text { Woodstock: } 28.0 \\
\text { Sarnia: } 9.6\end{array}$ & $\begin{array}{l}3.4-10.8 \\
9.7-46.4 \\
2.5-16.8\end{array}$ \\
\hline & $\begin{array}{l}\text { Roberts- } \\
\text { Thomson } \\
\text { et al. [39] }\end{array}$ & $\begin{array}{l}\text { South } \\
\text { Australia }\end{array}$ & $\begin{array}{l}\text { Analysis of the database of the South } \\
\text { Australian Scleroderma Register }\end{array}$ & All & $1993-2002$ & 21.4 & $20.2-22.6$ \\
\hline \multirow[t]{4}{*}{ SLE } & $\begin{array}{l}\text { Somers } \\
\text { et al. }[40]\end{array}$ & $\begin{array}{l}\text { Southeastern } \\
\text { Michigan, USA }\end{array}$ & $\begin{array}{l}\text { Analysis of multiple case-finding sources } \\
\text { in Wayne and Washtenaw counties } \\
\text { (population } 2.4 \text { million) }\end{array}$ & All & $2002-2004$ & $\begin{array}{l}\text { All ethnic groups: } 72.8 \\
\text { Black: } 111.6 \\
\text { White: } 47.5 \\
\text { Asian/Pacific Islander: } 4.4 \\
\text { Hispanic: } 42.1 \\
\end{array}$ & $\begin{array}{c}70.8-74.8 \\
107.7-115.6 \\
45.5-49.7 \\
1.4-10.4 \\
35.0-50.2\end{array}$ \\
\hline & $\begin{array}{l}\text { Arnaud } \\
\text { et al. [41] }\end{array}$ & France & $\begin{array}{l}\text { Cases from the French national } \\
\text { administrative databases ( } 86 \% \text { of the } \\
\text { French population) }\end{array}$ & $\begin{array}{l}\text { All } \\
<19\end{array}$ & 2010 & $\begin{array}{l}47.0 \\
3.75\end{array}$ & $46.5-47.6$ \\
\hline & $\begin{array}{l}\text { Lerang } \\
\text { et al. [42] }\end{array}$ & Oslo, Norway & $\begin{array}{l}\text { Cases from } 5 \text { hospitals (population of } \\
580,000 \text {, of whom } 20 \% \text { are immigrants of } \\
\text { non-European origin) }\end{array}$ & $\geq 16$ & Jan 1,2008 & $\begin{array}{l}\text { Ethnic Norwegian population: } 52.8 \\
\text { European descent immigrants: } 35.5 \\
\text { Asian population: } 59.7 \\
\text { In foreign country adopted population: } \\
\quad 307.0\end{array}$ & $\begin{array}{l}45.2-58.4 \\
17.6-53.5 \\
38.0-81.5 \\
75.4-538.7\end{array}$ \\
\hline & $\begin{array}{l}\text { Johnson } \\
\text { et al. [43] }\end{array}$ & $\begin{array}{l}\text { Birmingham, } \\
\text { UK }\end{array}$ & $\begin{array}{l}\text { Attending physicians }(\mathrm{n}=204) \text { were } \\
\text { contacted twice by mail with requests } \\
\text { about their SLE patients (population a } \\
\text { broad ethnic mix) }\end{array}$ & $\geq 18$ & Jan 1,1992 & $\begin{array}{l}\text { All ethnic groups: } 27.7 \\
\text { Afro-Caribbean: } 111.8 \\
\text { Asian: } 46.7 \\
\text { Caucasian: } 20.7\end{array}$ & $\begin{array}{l}24.2-31.2 \\
80.8-142.8 \\
31.5-61.9 \\
17.5-24.0\end{array}$ \\
\hline
\end{tabular}

Prevalence estimate: the prevalence is a point prevalence if it was reported for a specific point in time (i.e. a specific day and year), but it is a period prevalence if it was reported for a specified period (e.g. months or years).

\section{Discussion}

Skin and skin-related diseases accounted for a high percentage of all medical visits both in Olmsted County [4] and around the world [44]. The REP has been used to study the prevalence of certain specific skin diseases. For these specific skin diseases, we found the highest prevalences among patients with HS, psoriasis, and psoriatic arthritis, whereas the SLE and its subtypes, scleroderma, and $\mathrm{DM}$ were rare.
Estimates of prevalence are critically dependent on the study methodology used. All REP studies were based on population-based cohorts where the diagnosis of a disease had been confirmed by a physician. We compared these data to studies from other population-based cohorts in which data were drawn from other hospital registries, general practice, or established registries such as insurance data. Other prevalence studies were based on data gathered from self-reported patients and/or questionnaires. We noted that registry data mostly provided 


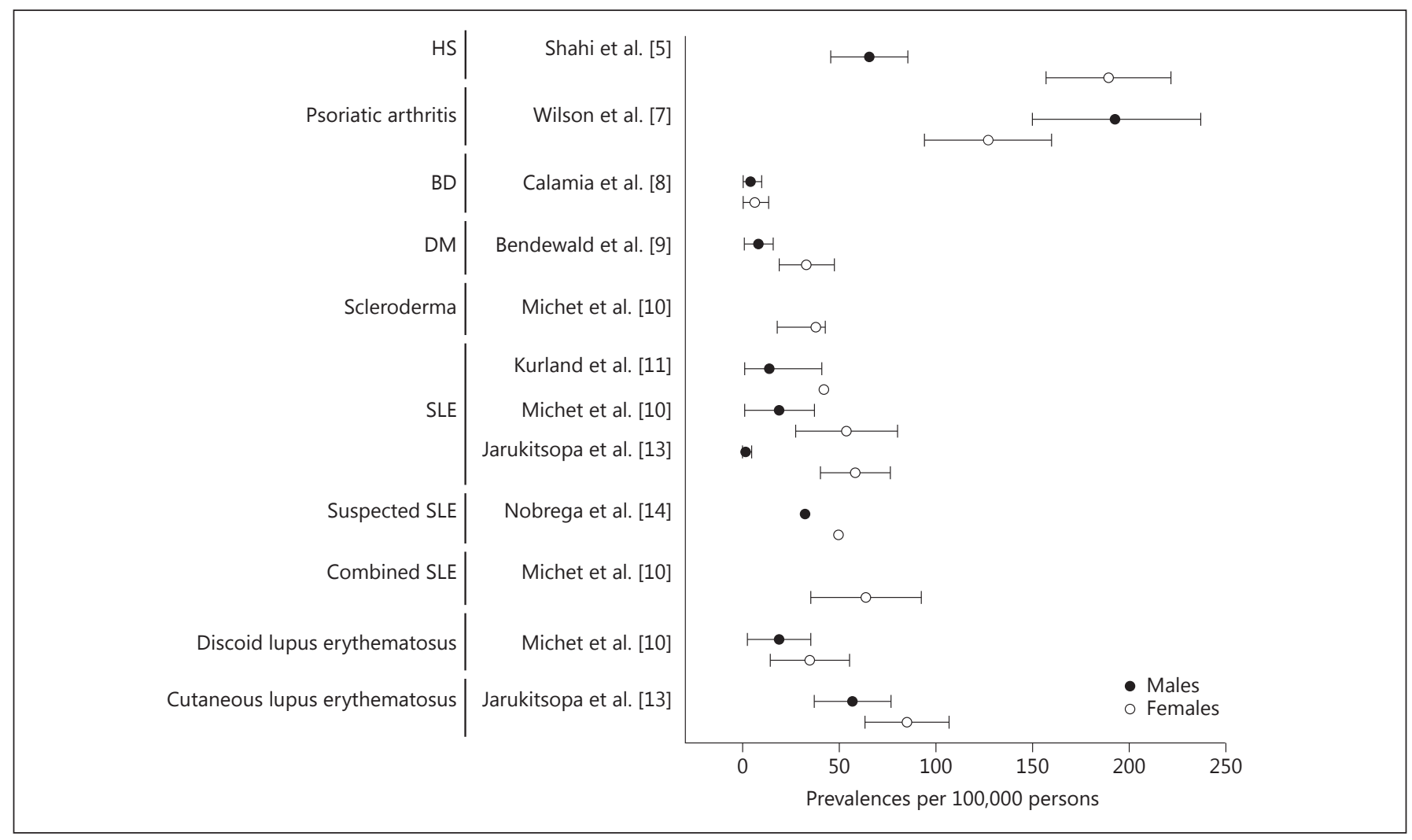

Fig. 2. Sex-specific prevalences of skin and skin-related diseases in Olmsted County, Minn., USA.

the lowest estimates of prevalences, particularly when compared to studies in which estimated data were based on self-reported patients.

As expected, the prevalence of skin and skin-related diseases varied between Olmsted County and other countries, states, or areas, suggesting a role for environmental and/or genetic factors in the pathogenesis. For example, the prevalence of BD was higher in Turkey [31] compared to Olmsted County [8], other European countries [28, 29], and Taiwan [30]. The prevalence of HS in South Wales did vary between areas, with the highest prevalence in an urban practice compared to a practice in an industrial valley [18]. Between Italian regions, a 2.8-times higher prevalence of psoriasis was reported in the central regions compared to Sardinia and the Southern region (Calabria, Apulia, and Basilicata), also suggesting a possible association with sunlight exposure and weather [23]. Between two areas in the Czech Republic, the highest prevalence was reported in the district of Cheb (a rural area) compared to the City of Ceske Budejovice (an urban area) [24]. In southwestern Ontario, Canada, the prevalences of scleroderma also varied between the areas of Windsor, Sarnia, and Woodstock. Interestingly, it was noted that scleroderma patients in these areas were more likely to drink alcohol [38]. In southern Australia, a lower prevalence of DM was reported [33] compared to other countries as well as Olmsted County $[9,32,34,35]$. This study found a possible association between DM and a higher socioeconomic status [33].

Most of the skin and skin-related diseases studied in Olmsted County were more common in females compared to males (fig. 2) [5, 7-11, 13, 14]. Similar differences were reported elsewhere (fig. 3) [19, 24-26, 29, 30, $34,36,37,40-43]$, showing that differences in skin layers, physiology, and sex hormones also affect the pathogenesis.

The population of Olmsted County is a predominantly white US population. Other prevalence studies have demonstrated that certain skin diseases are more prevalent in black populations. For example, in the Detroit TriCounty Area in the USA, the black population had a higher prevalence of scleroderma when compared with the 


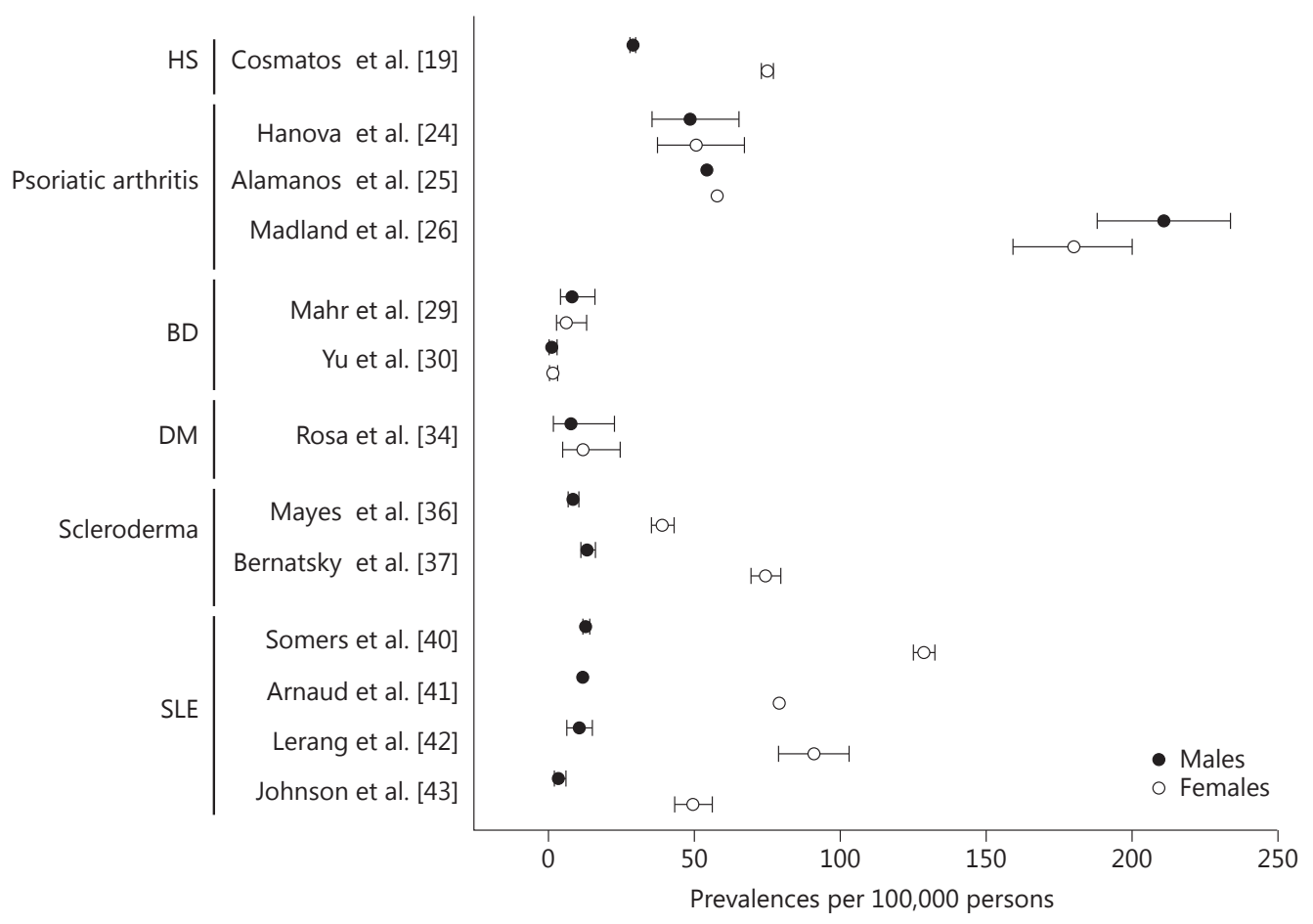

Fig. 3. Sex-specific prevalences of skin and skin-related diseases globally.

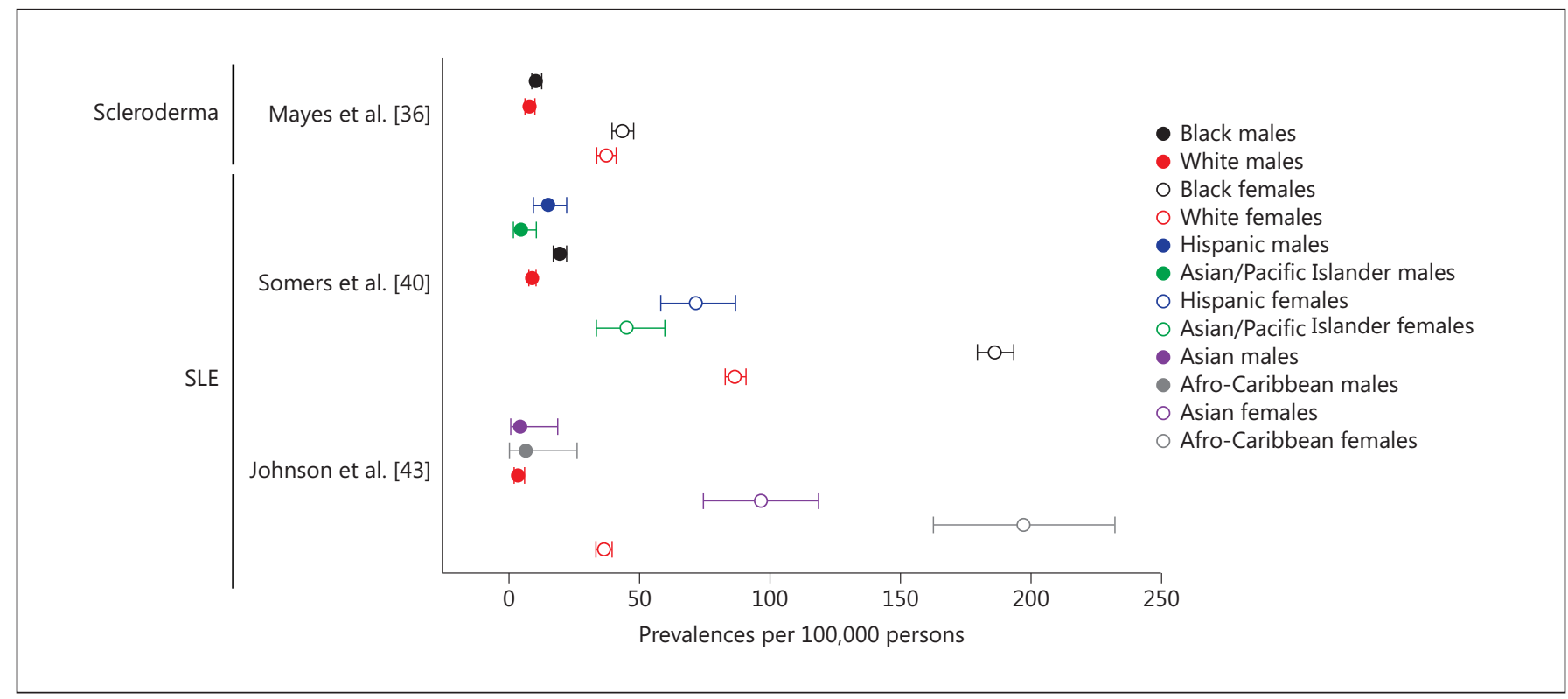

Fig. 4. Sex-specific prevalences of skin and skin-related diseases by ethnic groups. 
white population [36]. In southeastern Michigan, USA, the prevalence of SLE was highest among the black female population, followed by the white, Hispanic, and Asian/ pacific Islander female populations [40]. Similar differences between ethnic groups were found for SLE prevalences in Birmingham, UK, with the highest prevalence reported among Afro-Caribbean females followed by Asian and white females, irrespective of place of birth (fig. 4) [36, 40, 43]. For BD, when looking at people living in metropolitan areas in Paris, France, the prevalence was highest among people of North African origin, followed by Asian (incl. Turkish), noncontinental French, sub-Saharan African, and European nationality [29], irrespective of place of birth. Also shown were disease susceptibility differences among ethnic groups. On the other hand, the prevalence of psoriasis was found to be more common among the white population compared to African-Americans in the USA [20].

In summary, the results of the above prevalence studies were determined by many factors, such as type of prevalence, study methodology, geographic areas, ethnic group, age distribution and socioeconomic status.

\section{Limitation}

In addition, there are various possible issues when comparing prevalence data: (1) the definition of the prevalence - the prevalence data were either reported as a point prevalence or period prevalence; (2) different study methodologies - data were either drawn from a population-based source such as hospital, general practice, or established registers such as insurance data or from selfreported patients and/or questionnaires; (3) different dates/years of prevalences - the prevalences were reported from a number of different dates and years; (4) geographical areas - the reported prevalence comes from different countries or areas; (5) different ethnic groups - the prevalences may reflect a certain ethnic group (e.g. black or white population) more accurately and may not represent the entire population of a country; (6) different categorization of a skin and skin-related disease - certain studies have used the International Classification of Diseases categories or other classification criteria to determine if the patient had the disease, while others were not confirmed by a physician, but by the patients; (7) age groups - the reported prevalences may represent a certain age group (e.g. adults only or children only) and therefore not represent the overall prevalence in the entire population across all ages.

\section{Conclusion}

Skin and skin-related diseases are an important public health concern. Describing public health issues from an epidemiologic perspective can increase an understanding of the potential impact and provide a basis for developing and prioritizing public health programs. The prevalence of skin and skin-related disease varies from study to study, and many factors contribute to these differences.

\section{Acknowledgments}

We acknowledge Jill M. Killian and Amy L. Weaver for their assistance with statistical review and analysis of the data.

This study was made possible using the resources of the REP, which is supported by the National Institute on Aging of the National Institutes of Health under Award No. R01AG034676.

\section{Disclosure Statement}

The authors have no conflicts of interest to disclose.

\section{References}

1 Andersen LK, Davis MD: The epidemiology of skin and skin-related diseases: a review of population-based studies performed by using the Rochester Epidemiology Project. Mayo Clin Proc 2013;88:1462-1467.

2 Melton LJ 3rd: History of the Rochester Epidemiology Project. Mayo Clin Proc 1996;71: 266-274.

-3 Rocca WA, Yawn BP, St Sauver JL, Grossardt BR, Melton LJ 3rd: History of the Rochester Epidemiology Project: half a century of medical records linkage in a US population. Mayo Clin Proc 2012;87:1202-1213.
-4 St Sauver JL, Warner DO, Yawn BP, Jacobson DJ, McGree ME, Pankratz JJ, Melton LJ 3rd, Roger VL, Ebbert JO, Rocca WA: Why patients visit their doctors: assessing the most prevalent conditions in a defined American population. Mayo Clin Proc 2013;88:56-67.

5 Shahi V, Alikhan A, Vazquez BG, Weaver AL, Davis MD: Prevalence of hidradenitis suppurativa: a population-based study in Olmsted County, Minnesota. Dermatology 2014;229: 154-158.

-6 Shbeeb M, Uramoto KM, Gibson LE, O'Fallon WM, Gabriel SE: The epidemiology of psori- atic arthritis in Olmsted County, Minnesota, USA, 1982-1991. J Rheumatol 2000;27:12471250.

7 Wilson FC, Icen M, Crowson CS, McEvoy MT, Gabriel SE, Kremers HM: Time trends in epidemiology and characteristics of psoriatic arthritis over 3 decades: a population-based study. J Rheumatol 2009;36:361-367.

$>8$ Calamia KT, Wilson FC, Icen M, Crowson CS, Gabriel SE, Kremers HM: Epidemiology and clinical characteristics of Behçet's disease in the US: a population-based study. Arthritis Rheum 2009;61:600-604. 
-9 Bendewald MJ, Wetter DA, Li X, Davis MD: Incidence of dermatomyositis and clinically amyopathic dermatomyositis: a populationbased study in Olmsted County, Minnesota. Arch Dermatol 2010;146:26-30.

10 Michet CJ Jr, McKenna CH, Elveback LR, Kaslow RA, Kurland LT: Epidemiology of systemic lupus erythematosus and other connective tissue diseases in Rochester, Minnesota, 1950 through 1979. Mayo Clin Proc 1985;60: 105-113.

-11 Kurland LT, Hauser WA, Ferguson RH, Holley KE: Epidemiologic features of diffuse connective tissue disorders in Rochester, Minn., 1951 through 1967, with special reference to systemic lupus erythematosus. Mayo Clin Proc 1969;44:649-663.

- 12 Uramoto KM, Michet CJ Jr, Thumboo J, Sunku J, O'Fallon WM, Gabriel SE: Trends in the incidence and mortality of systemic lupus erythematosus, 1950-1992. Arthritis Rheum 1999;42:46-50.

-13 Jarukitsopa S, Hoganson DD, Crowson CS, Sokumbi O, Davis MD, Michet CJ Jr, Matteson EL, Maradit Kremers H, Chowdhary VR: Epidemiology of systemic lupus erythematosus and cutaneous lupus erythematosus in a predominantly white population in the United States. Arthritis Care Res (Hoboken) 2015; 67:817-828.

14 Nobrega F, Ferguson RH, Kurland LT, Hargraves MM: Lupus erythematosus in Rochester, Minnesota, 1950-1965: a preliminary study. In: Proceedings of the Third International Symposium on Population Studies of the Rheumatic Diseases. Excerpta Medica International Congress Series No 148. New York, Excerpta Medica, 1966, pp 259-266.

-15 Durosaro O, Davis MD, Reed KB, Rohlinger AL: Incidence of cutaneous lupus erythematosus, 1965-2005: a population-based study. Arch Dermatol 2009;145:249-253.

16 Jemec GB, Heidenheim M, Nielsen NH: The prevalence of hidradenitis suppurativa and its potential precursor lesions. J Am Acad Dermatol 1996;35:191-194.

$\checkmark 17$ Revuz JE, Canoui-Poitrine F, Wolkenstein P, Viallette C, Gabison G, Pouget F, Poli F, Faye O, Roujeau JC, Bonnelye G, Grob JJ, BastujiGarin S: Prevalence and factors associated with hidradenitis suppurativa: results from two case-control studies. J Am Acad Dermatol 2008;59:596-601.

18 Harrison BJ, Mudge M, Hughes LE: The prevalence of hidradenitis in South Wales; in Marks R, Plewig G (eds): Acne and Related Disorders. London, Dunitz, 1991, pp 365366.

19 Cosmatos I, Matcho A, Weinstein R, Montgomery MO, Stang P: Analysis of patient claims data to determine the prevalence of hidradenitis suppurativa in the United States. J Am Acad Dermatol 2013;68:412-419.

-20 Gelfand JM, Stern RS, Nijsten T, Feldman SR, Thomas J, Kist J, Rolstad T, Margolis DJ: The prevalence of psoriasis in African Americans: results from a population-based study. J Am Acad Dermatol 2005;52:23-26.

21 Nevitt GJ, Hutchinson PE: Psoriasis in the community: prevalence, severity and patients beliefs and attitudes towards the disease. $\mathrm{Br} J$ Dermatol 1996;135:533-537.

22 Augustin M, Glaeske G, Radtke MA, Christophers E, Reich K, Schafer I: Epidemiology and comorbidity of psoriasis in children. Br J Dermatol 2010;162:633-636.

23 Saraceno R, Mannheimer R, Chimenti S: Regional distribution of psoriasis in Italy. J Eur Acad Dermatol Venereol 2008;22:324-329.

24 Hanova P, Pavelka K, Holcatova I, Pikhart H: Incidence and prevalence of psoriatic arthritis, ankylosing spondylitis, and reactive arthritis in the first descriptive populationbased study in the Czech Republic. Scand J Rheumatol 2010;39:310-317.

25 Alamanos Y, Papadopoulos NG, Voulgari PV, Siozos C, Psychos DN, Tympanidou M, Drosos AA: Epidemiology of psoriatic arthritis in northwest Greece, 1982-2001. J Rheumatol 2003;30:2641-2644.

26 Madland TM, Apalset EM, Johannessen AE, Rossebo B, Brun JG: Prevalence, disease manifestations, and treatment of psoriatic arthritis in western Norway. J Rheumatol 2005;32: 1918-1922.

27 Salaffi F, De Angelis R, Grassi W: Prevalence of musculoskeletal conditions in an Italian population sample: results of a regional community-based study. I. The mapping study. Clin Exp Rheumatol 2005;23:819-828.

28 Salvarani C, Pipitone N, Catanoso MG, Cimino L, Tumiati B, Macchioni P, Bajocchi G, Olivieri I, Boiardi L: Epidemiology and clinical course of Behçet's disease in the Reggio Emilia area of northern Italy: a seventeen-year population-based study. Arthritis Rheum 2007;57:171-178.

29 Mahr A, Belarbi L, Wechsler B, Jeanneret D, Dhote R, Fain O, Lhote F, Ramanoelina J, Coste J, Guillevin L: Population-based prevalence study of Behcet's disease: differences by ethnic origin and low variation by age at immigration. Arthritis Rheum 2008;58:39513959.

$30 \mathrm{Yu}$ KH, See LC, Kuo CF, Chou IJ, Chou MJ: Prevalence and incidence in patients with autoimmune rheumatic diseases: a nationwide population-based study in Taiwan. Arthritis Care Res (Hoboken) 2013;65:244-250.

-31 Azizlerli G, Kose AA, Sarica R, Gul A, Tutkun IT, Kulac M, Tunc R, Urgancioglu M, Disci R: Prevalence of Behcet's disease in Istanbul, Turkey. Int J Dermatol 2003;42:803-806.

-32 Furst DE, Amato AA, Iorga SR, Gajria K, Fernandes AW: Epidemiology of adult idiopathic inflammatory myopathies in a US managed care plan. Muscle Nerve 2012;45:676-683.

33 Tan JA, Roberts-Thomson PJ, Blumberg P, Hakendorf P, Cox SR, Limaye V: Incidence and prevalence of idiopathic inflammatory myopathies in south Australia: a 30-year epi- demiologic study of histology-proven cases. Int J Rheum Dis 2013;16:331-338.

- 34 Rosa J, Garrot LF, Navarta DA, Saucedo C, Scolnik M, Bedran Z, Garcia MV, Sabelli M, Catoggio LJ, Soriano ER: Incidence and prevalence of polymyositis and dermatomyositis in a health management organization in Buenos Aires. J Clin Rheumatol 2013;19:303307.

35 Anagnostopoulos I, Zinzaras E, Alexiou I, Papathanasiou AA, Davas E, Koutroumpas A, Barouta G, Sakkas LI: The prevalence of rheumatic diseases in central Greece: a population survey. BMC Musculoskelet Disord 2010;11: 98.

36 Mayes MD, Lacey JV Jr, Beebe-Dimmer J, Gillespie BW, Cooper B, Laing TJ, Schottenfeld D: Prevalence, incidence, survival, and disease characteristics of systemic sclerosis in a large US population. Arthritis Rheum 2003; 48:2246-2255.

37 Bernatsky S, Joseph L, Pineau CA, Belisle P, Hudson M, Clarke AE: Scleroderma prevalence: demographic variations in a population-based sample. Arthritis Rheum 2009;61: 400-404.

38 Thompson AE, Pope JE: Increased prevalence of scleroderma in southwestern Ontario: a cluster analysis. J Rheumatol 2002;29:18671873.

39 Roberts-Thomson PJ, Walker JG, Lu TY, Esterman A, Hakendorf P, Smith MD, Ahern MJ: Scleroderma in south Australia: further epidemiological observations supporting a stochastic explanation. Intern Med J 2006;36: 489-497.

40 Somers EC, Marder W, Cagnoli P, Lewis EE, DeGuire P, Gordon C, Helmick CG, Wang L, Wing JJ, Dhar JP, Leisen J, Shaltis D, McCune WJ: Population-based incidence and prevalence of systemic lupus erythematosus: the Michigan Lupus Epidemiology and Surveillance Program. Arthritis Rheum 2014;66: 369-378.

41 Arnaud L, Fagot JP, Mathian A, Paita M, Fagot-Campagna A, Amoura Z: Prevalence and incidence of systemic lupus erythematosus in France: a 2010 nation-wide population-based study. Autoimmun Rev 2014;13: 1082-1089.

42 Lerang K, Gilboe I, Garen T, Thelle DS, Gran JT: High incidence and prevalence of systemic lupus erythematosus in Norway. Lupus 2012;21:1362-1369.

43 Johnson AE, Gordon C, Palmer RG, Bacon PA: The prevalence and incidence of systemic lupus erythematosus in Birmingham, England. Relationship to ethnicity and country of birth. Arthritis Rheum 1995;38:551-558.

44 Hay RJ, Johns NE, Williams HC, Bolliger IW, Dellavalle RP, Margolis DJ, Marks R, Naldi L, Weinstock MA, WulfSK, Michaud C, Murray JLC, Naghavi M: The global burden of skin disease in 2010: an analysis of the prevalence and impact of skin conditions. J Invest Dermatol 2014;134:1527-1534. 